\title{
¿Cuál sería su diagnóstico?
}

\section{What should the diagnosis be?}

Mujer de 63 años con cuadro de dos años de evolución de edema labial y hemifacial de instauración brusca, acompañada en algunas ocasiones de cortejo vegetativo (taquicardia, sudoración).

Los episodios de tumefacción de labio y hemicara izquierdos (Figs. 1 y 2) se han dado en cuatro ocasiones con aproximadamente 48-72 horas de duración de cada uno de ellos.

Entre los antecedentes personales de la paciente destaca la existencia de dos episodios de parálisis facial transitoria en 1978 y 1979
The case is presented of a 63-year-old female with symptoms that had been evolving for two years that included hemifacial and lip edema. The onset had been sudden and on some occasions she had had symptoms of palpitations* and sweating.

The episodes of swelling affecting the left side of her face and lip (Fig. 1 and 2) had occurred on four occasions and each episode had lasted 48-72 hours.

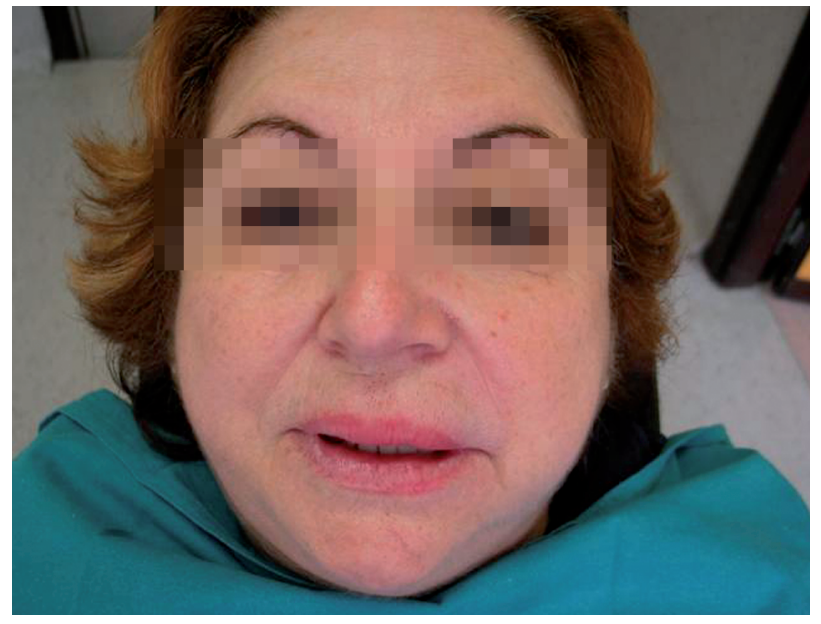

Figura 1.

Figure 1.

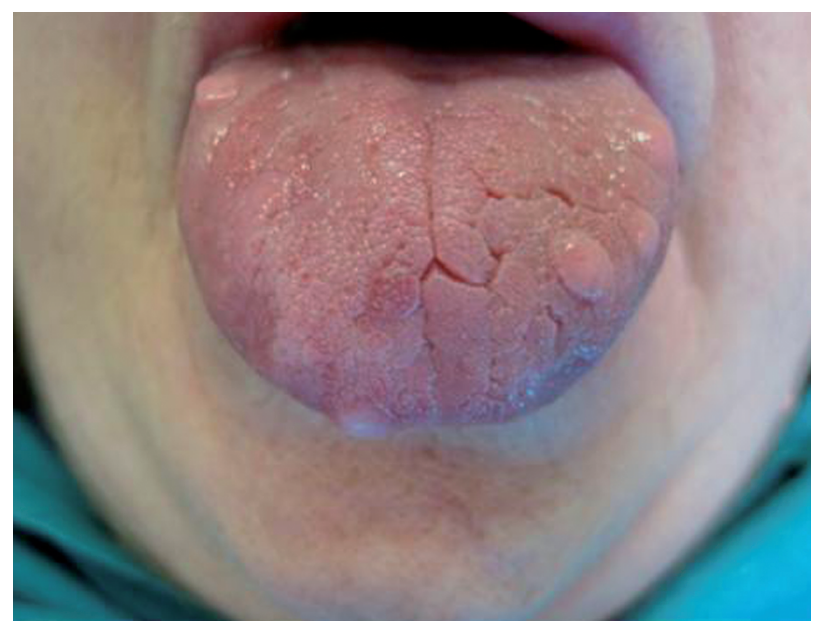

Figura 3.

Figure 3.

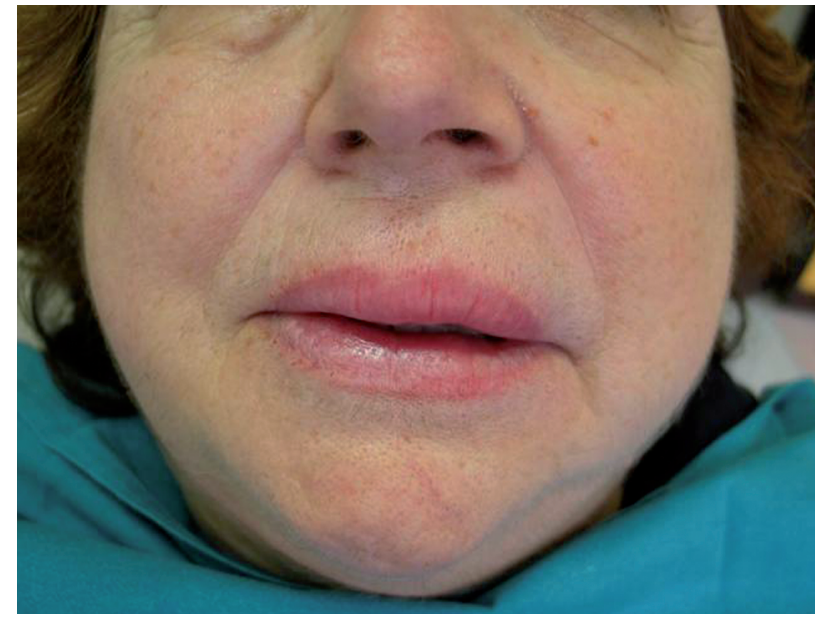

Figura 2.

Figure 2.

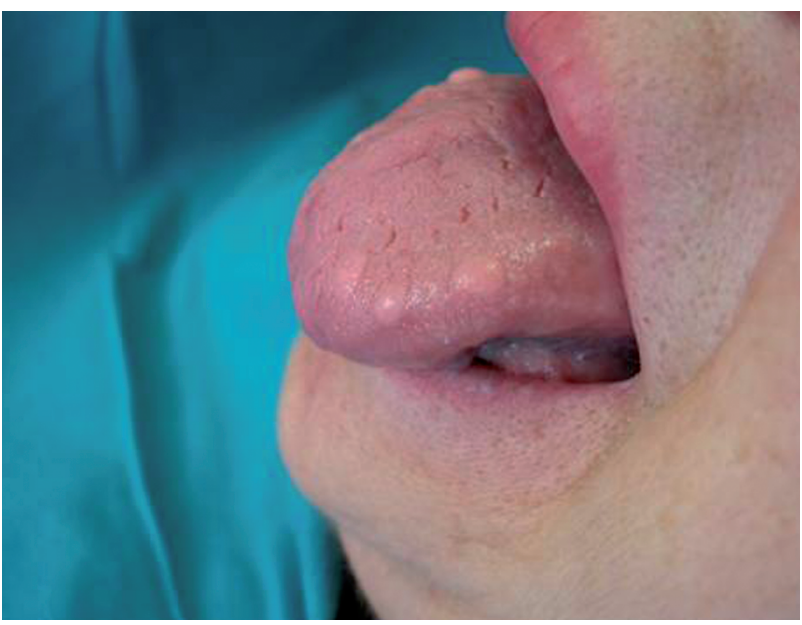

Figura 4.

Figure 4. 
que no se han vuelto a repetir. La lengua presenta lesiones de aspecto fibroso (Figs. 3 y 4 ) especialmente en borde izquierdo, y presencia de surcos transversales en dorso lingual, así como discreta macroglosia.

En los estudios analíticos únicamente destaca una discreta eosinofilia de 1,2\%. El estudio inmunológico es normal (niveles de C3, C4 e inhibidor de C1 normales).

Los niveles de Ig E se encuentran ligeramente elevados (118, con un rango de normalidad de 0-100).

Se toman dos biopsias, de la lengua y el labio respectivamente. Las lesiones linguales se corresponden con epitelio pavimentoso con ligera acantosis (Figs. 5 y 6). La biopsia del labio se describe como glándulas con diferenciación mucosa, rodeadas por agregados linfoides inespecíficos (Figs. 7 y 8 ).
Of note in her medical history were two episodes of transitory facial palsy in 1978 and 1979 that had not reoccurred. Her tongue had lesions of a fibrous appearance (Fig. 3 and 4) particularly around the left border, and there were transverse fissures on the back of her tongue and slight macroglossia.

Her blood tests revealed slight eosinophilia of $1.2 \%$. Her immunological tests were normal (C3, C4 and normal C1 inhibitor). IgE levels were slightly elevated (118, normal range 0-100).

Two biopsies were taken, one from the tongue and the other from the lip. The lesions of the tongue corresponded to pavement epithelium with slight acanthosis (Figs. 5 and 6). The biopsy report of the lip described glands with mucosal differentiation surrounded by unspecific lymphoid aggregates (Figs. 7 and 8).

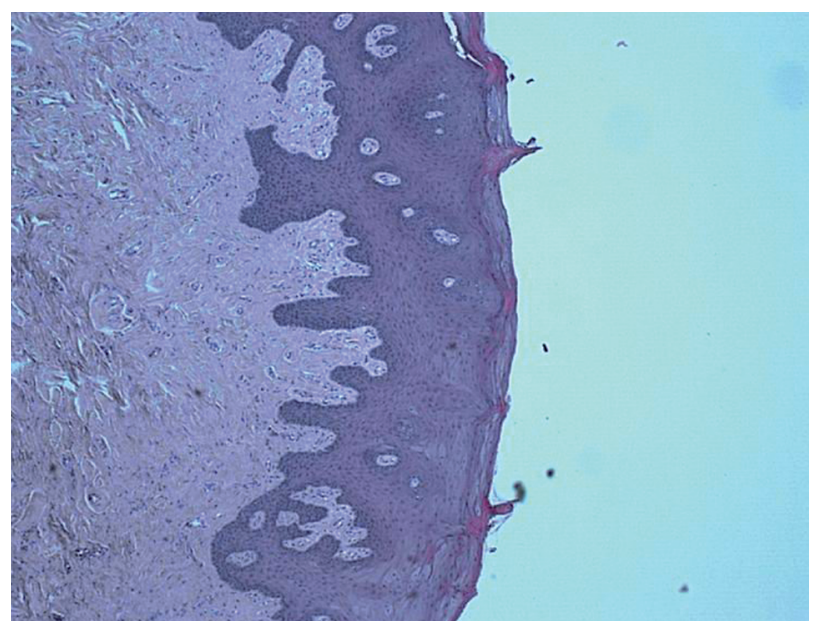

Figura 5.

Figure 5.

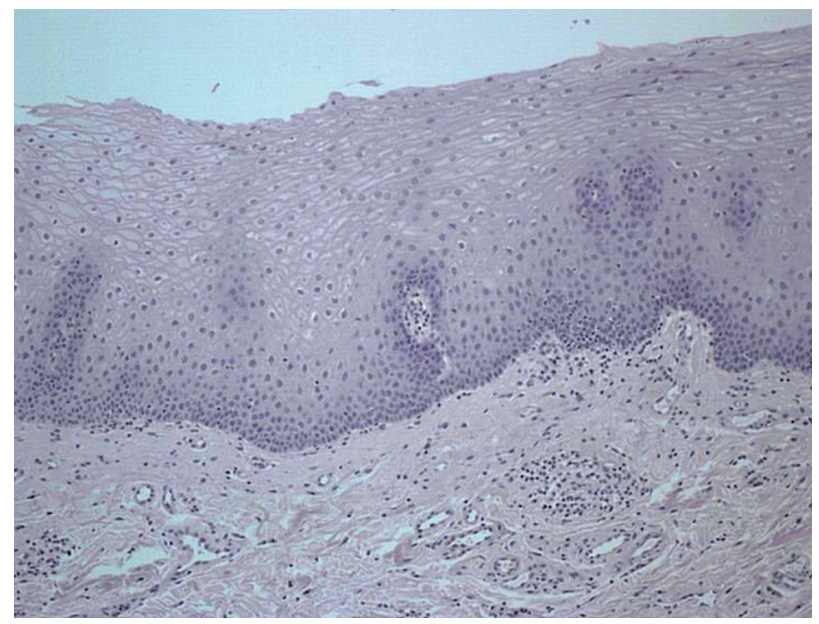

Figura 7.

Figure 7.

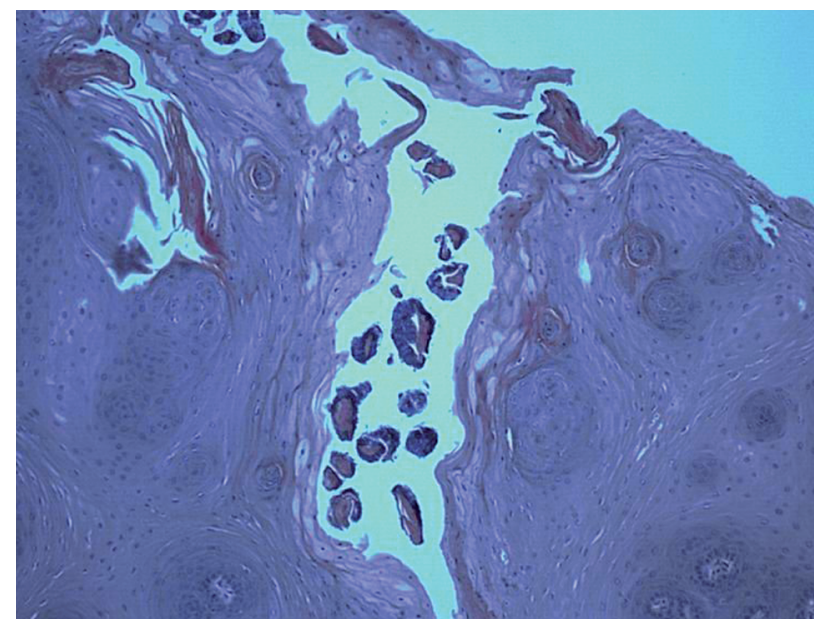

Figura 6.

Figure 6.

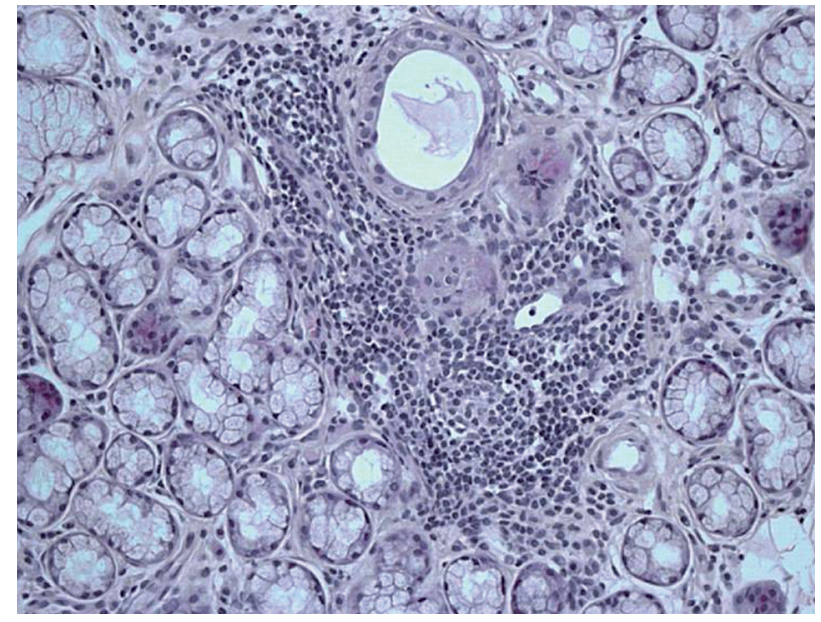

Figura 8.

Figure 8. 


\title{
Síndrome de Melkersson-Rosenthal
}

\author{
Melkersson-Rosenthal syndrome
}

\author{
L. Gallego López1', S. Llorente Pendás², J.S. López-Arranz ${ }^{3}$
}

\section{Introducción}

El síndrome de Melkersson-Rosenthal (SMR) es un síndrome clínico caracterizado por la triada: parálisis facial idiopática, lengua fisurada y edema orofacial, si bien abundan más las formas oligosintomáticas o monosintomáticas de la enfermedad. La forma monosintomática más común se conoce como queilitis granulomatosa de Meischer, y cursa con edema labial recurrente de uno o ambos labios, que puede llegar a ser persistente. ${ }^{1}$

El edema orofacial (Figs. 1 y 2) es el signo más frecuente de la triada (aparece en la práctica totalidad de los pacientes en algún momento del curso de la enfermedad) y suele ser la primera manifestación del SMR en la mayoría de los casos.

La parálisis facial puede ser bilateral o unilateral, predominando ésta última, parcial o completa. Es clínicamente indistinguible de la parálisis idiopática de Bell. Su curso es recurrente con recuperación espontánea, aunque puede llegar a dejar disquinesias o parálisis residual. Afecta aproximadamente a un tercio de los pacientes.

La lengua plicata o fisurada (Figs. 3 y 4 ) es el signo más inespecífico del SMR, que aparece en aproximadamente en el 50\% de los pacientes, y es con frecuencia hereditaria. Consiste en una lengua de tamaño ligeramente mayor al normal, con abundantes surcos transversales en el dorso de la misma conectados a un surco longitudinal principal.

Además de estos tres signos principales o mayores el SMR puede presentar otros signos menores, ${ }^{2}$ como son la afectación de otros pares craneales (especialmente el $V$ par o nervio trigémino), vértigo, acúfenos, migrañas, transtornos del sistema nervioso autónomo (náuseas, vómitos, espasmos), incluso transtornos psiquiátricos.

\footnotetext{
1 Médico Residente

2 Médico Adjunto

3 Jefe de Servicio

Servicio de Cirugía Oral y Maxilofacial

Hospital Universitario Central de Asturias, Oviedo. España
}

\section{Correspondencia:}

L. Gallego López

Servicio de Cirugía Oral y Maxilofacial

Hospital Universitario Central de Asturias

C/ Celestino Villamil, s/n

33006 Oviedo, Asturias, España

\section{Introduction}

Melkersson-Rosenthal syndrome (MRS) is a clinical syndrome characterized by a triad: idiopathic facial paralysis, fissured tongue and orofacial edema, although the oligosymptomatic or monosymptomatic forms of the disease are more common. The monosymptomatic form that is most common is known are Meischer's granulomatous cheilitis that entails recurrent labial edema of one or both lips that can become persistent. ${ }^{1}$

Orofacial edema (Figs. 1 and 2) is the most common sign of the triad (it appears in practically all patients at some point during the course of the disease) and it tends to be the first manifestation of MRS in most cases.

Facial palsy can be bilateral or unilateral, the latter being more predominant, and it can be partial or complete. It is indistinguishable clinically from Bell's idiopathic paralysis. It has a recurrent course with spontaneous recovery, although dyskinesias or residual paralysis may remain. It affects approximately a third of patients.

The plicated or fissured tongue (Figs. 3 and 4) is a more unspecific sign of MRS that appears in approximately $50 \%$ of patients, and it is frequently hereditary. It consists of a tongue that is slightly larger than normal, with large numbers of fissures crossing the back of it which are connected to a main fissure that is longitudinal.

In addition to these three main or major signs of MRS, there can be other minor signs, ${ }^{2}$ such as other cranial nerve involvement (especially the 5th pair or trigeminal nerve), vertigo, buzzing, migraines, disturbance of the autonomic nervous system (nauseas, vomiting, spasms), even psychiatric disturbances.

The prevalence of MRS is estimated at around $0.08 \%$ of the general population, although it is believed to be underdiagnosed. It affects both sexes equally, there being a slight predominance in females, and it tends to appear in the second decade of life. ${ }^{2}$

The etiology behind MRS is still unknown, although numerous hypotheses have been put forward. ${ }^{3}$ There are certain signs of a genetic predisposition, and the existence of a 
La prevalencia del SMR se estima en torno al 0,08\% de la población general, aunque se piensa que puede estar infradiagnosticado. Afecta por igual en ambos sexos, o con ligero predominio femenino, y suele debutar en la segunda década de la vida. ${ }^{2}$

La etiología del SMR es todavía desconocida, aunque se han barajado numerosas hipótesis. ${ }^{3}$ Ciertamente existen evidencias de una predisposición genética, incluso se ha hablado del gen del SMR, situado en el cromosoma 9p11, aunque parece aplicable sólo a algunos casos de lengua fisurada. ${ }^{2}$ Otros patrones de herencia contemplados es el autonómico dominante con expresividad variable y herencia poligénica. ${ }^{4}$ Otros autores defienden la teoría de una causa infecciosa, especialmente relacionado con el virus del herpes simple. ${ }^{3}$ Finalmente, los factores autoinmunes también parecen tener un papel en el desarrollo etiopatogénico de esta entidad, como indica su asociación con artritis reumatoide, incluso hay autores que lo han considerado una variante clínica de la sarcoidosis. ${ }^{3}$

El diagnóstico es fundamentalmente clínico, aunque debe realizarse una confirmación histopatológica. La histopatología se caracteriza en un buen número de casos por una inflamación granulomatosa, siendo representativos del síndrome los granulomas epiteliodes no caseosos (indistinguibles del granulomas sarcoideos), aunque su ausencia no excluye el diagnóstico. Así, también es posible encontrar una histopatología inflamatoria totalmente inespecífica, o encontrar células gigantes de Langhans e infiltrado mononuclear perivascular.

\section{Discusión}

La parálisis facial, el edema facial recurrente y la lengua fisurada constituyen una triada clínica que define el síndrome de Melkersson-Rosenthal, siendo la tríada completa más infrecuente que la presentación oligosintomática de la enfermedad. ${ }^{5}$

El diagnóstico se ha de estar basado en los signos clínicos, aunque está aconsejada la toma de una biopsia para realizar una confirmación del mismo, con el hallazgo característico de granulomas epiteliodes no caseificantes, si bien su ausencia no excluye el diagnóstico, porque el SMR puede adoptar otras manifestaciones histopatológicas, incluyendo un infiltrado inflamatorio totalmente inespecífico, como ocurre en el caso que nos ocupa.

Ha de hacerse el diagnóstico diferencial con otras entidades (Tabla 1), como son las malformaciones vasculares labiales, la queilitis glandular, la erisipela recurrente, el angioedema hereditario (que se acompaña de edema de vías aéreas superiores y déficit del inhibidor de $\mathrm{C} 1$ del complemento), el síndrome de Ascher, ${ }^{6}$ la enfermedad de Crohn o la sarcoidosis.

No existe una terapia estandarizada para este síndrome, ya que todavía no se entienden los mecanismos etiopatogénicos del mismo, ensayándose numerosos tratamientos con resultados variables (Tabla 2). Los fármacos más utilizados son los corticoides, ${ }^{4}$ sistémicos, tópicos o intralesionales, solos o en combinación con la minociclina, que parece aumentar la efectividad, si bien éste último fármaco está contraindicado en niños menores de 8 años. La clofamicina, un agente antimicrobiano y antiinflamatorio usado comúnmente para el tratamiento de la tuberculosis y la lepra, está siendo usado en
MRS gene situated in chromosome 9 p11 has been discussed, although it appears applicable to just some cases of fissured tongues. ${ }^{2}$ Other patterns that have been studied are autosomal dominant inheritance with variable expressivity and polygenic inheritance. ${ }^{4}$ Other authors defend the theory of infection, connected in particular with the herpes simplex virus. ${ }^{3}$ Finally, autoimmune factors seem also to have a role in the etiopathogenic development of this entity, as is indicated in its association with rheumatoid arthritis, and there are even authors that have considered it a clinical variant of sarcoidosis. ${ }^{3}$

The diagnosis is essentially clinical, although histopathologic confirmation should be carried out. The histopathology is characterized in a good number of cases by granulomatous inflammation, with non-caseating epithelioid granulomas being representative of the syndrome (indistinguishable from sarcoid granulomas), although its absence does not exclude the diagnosis. It is also possible for the histopathology of the inflammation to be completely unspecific, as is finding Langhans giant cells or perivascular mononuclear infiltrate.

\section{Discussion}

Facial palsy, recurrent facial swelling and a fissured tongue form a clinical triad that defines Melkersson-Rosenthal syndrome. The complete triad is more uncommon than the oligosymptomatic presentation of the diesease. 5

The diagnosis should be based on clinical signs, although taking a biopsy is advisable for confirmation. The characteristic finding is non-caseating epithelioid granulomas, although their absence does not exclude the diagnosis, because MRS can adopt other different histopathologic manifestations, including totally unspecific inflammatory infiltrate, as occurred in the case presented.

The differential diagnosis has to be carried out with other entities (Table 1), such as vascular malformation of the lip, glandular cheilitis, recurrent erysipelas, hereditary angioedema (that is accompanied by edema of the upper airways and complement $\mathrm{C} 1$ inhibitor deficiency), Ascher syndrome, 6 Crohn's disease or sarcoidosis.

There is no standard therapy for this syndrome, as the etiopathogenic mechanisms behind it are still not understood, and numerous therapies have been tried with varying results (Table 2). The drugs that are most used are corticoid, ${ }^{4}$ systemic, topical, or intralesional, on their own or combined with minocycline that appears to increase effectiveness, although this last drug is contraindicated in children under the age of 8 . Clofazimine is an anti-microbial and anti-inflammatory agent that is commonly used for treating tuberculosis and leprosy. It has been used in recent studies with good results, but it has undesirable side effects such as orange-colored skin, corneal and intestinal problems. ${ }^{7}$ Thalidomide in $50 \mathrm{mg}$ a day doses over 6-8 weeks has turned 
Tabla 1. Diagnóstico diferencial del SMR

\begin{tabular}{|c|c|c|}
\hline Patología & Características del edema & Otros datos \\
\hline Síndrome de Melkersson-Rosenthal & Orofacial, firme, intermitente, no doloroso & Acompañado o no de parálisis facial y lengua escrotal \\
\hline $\begin{array}{l}\text { Malformaciones vasculares: } \\
\text { linfangioma, hemagioma }\end{array}$ & Pueden ser pulsátiles, no intermitentes & $\begin{array}{l}\text { DD por estudio anatomopatológico y estudios de } \\
\text { imagen }\end{array}$ \\
\hline Queilitis glandular & $\begin{array}{l}\text { Inflamación g.salivares menores, clínica } \\
\text { inflamatoria, formas supuradas }\end{array}$ & DD: anatomía patológica \\
\hline Erisipela recurrente & $\begin{array}{l}\text { Obstrucción de canales linfáticos, edema y } \\
\text { eritema con límites definidos }\end{array}$ & $\begin{array}{l}\text { Buena respuesta a antibióticos, fiebre, malestar } \\
\text { general, vómitos }\end{array}$ \\
\hline Angioedema hereditario & $\begin{array}{l}\text { Edema facial y de vías aéreas superiores, } \\
\text { brusco,desencadenado por estrés o cirugía, } \\
\text { no dolor ni prurito }\end{array}$ & Déficit de factor inhibidor de $\mathrm{C} 1$ \\
\hline Síndrome de Ascher & $\begin{array}{l}\text { Tumefacción labial progresiva y difusa } \\
\text { (labio superior), edemas repetidos de } \\
\text { párpados superiores, blefarocalasia }\end{array}$ & $\begin{array}{l}\text { Parálisis facial ausente, inflamación de glándula } \\
\text { lagrimal accesoria, bocio eutiroideo }\end{array}$ \\
\hline Enfermedad de Crohn & $\begin{array}{l}\text { Engrosamiento de mucosa oral y los labios, } \\
\text { granulomas cutáneos }\end{array}$ & Afectación intestinal, de extremidades inferiores \\
\hline Sarcoidosis & $\begin{array}{l}\text { Edema orofacial progresivo sin fluctuación } \\
\text { (30-50\% de localización en área orofacial) }\end{array}$ & $\begin{array}{l}\text { ECA en plasma elevados, hipercalcemia, afectación } \\
\text { pulmonar y mediatínica, test de Kveim positivo. } \\
\text { Idéntica anatomía patológica al SMR }\end{array}$ \\
\hline
\end{tabular}

Table 1. MRS differential diagnosis

\section{Pathology}

Melkersson-Rosenthal syndrome

Vascular malformations:

lymphangioma, hemangioma

Glandular cheilitis

Recurrent Erysipelas

Hereditary angioedema

Ascher's syndrome

Crohn's disease

Sarcoidosis

\section{Characteristics of the edema}

Orofacial, firm, intermittent, non-tender

May be with pulse, non-intermittent

Inflammation of minor salivary g., clinical signs of inflammation, suppuration types

Obstruction of lymphatic system, edema and erythema with defined borders

Sudden facial edema and of upper airways, started by stress or surgery, non-tender and no pruritus

Progressive and diffuse swelling of the lip (upper lip), repetitive edemas of upper eyelids, blepharochalasis

Thickening of oral mucosa, lips, cutaneous granulomas

Progressive orofacial edema without fluctuations (30-50\% located in orofacial area)

\section{Other data}

Accompanied or not by facial palsy and scrotal tongue

DD through anatomopathologic and imaging studies

DD: pathologic anatomy

Good response to antibiotics, fever, general sickness, vomiting

C1 inhibitor deficiency

Absence of facial palsy, inflammation of accessory lacrimal gland, euthyroid goiter

Intestinal disturbance, of lower limbs

High ACE plasma, hypercalcemia, lung and mediastinal involvement, positive Kveim test. Identical pathological anatomy to MRS estudios recientes con buenos resultados, pero tiene efectos colaterales indeseables como coloración anaranjada de la piel, problemas corneales e intestinales. ${ }^{7}$ La talidomida, en dosis de $50 \mathrm{mg} / \mathrm{d}$ alrededor de 6-8 semanas, ha resultado ser una droga efectiva en el manejo de SMR con escasos efectos secundarios, como la somnolencia, aunque su uso está absolutamente contraindicado en pacientes gestantes por su potencial teratógeno. out to be an effective drug for managing MRS with very few side effects, such as drowsiness, although its use it totally contraindicated in pregnant patients due to its teratogenic potential.

Surgical therapy is an alternative in cases of residual deformities and a lip cheiloplasty8 or surgical decompression of the facial nerve 9 can be carried out when there are recur- 
Tabla 2. Opciones terapéuticas de SMR

\begin{tabular}{|c|c|c|}
\hline Terapéutica & Posología & Efectos \\
\hline $\begin{array}{l}\text { Corticoides (prednisolona, triamcinolona): } \\
\text { - Tópicos } \\
\text { - Sistémicos } \\
\text { - Intralesionales }\end{array}$ & $\begin{array}{l}1 \mathrm{mg} / \mathrm{kg} \text { al dia durante } 8 \text { semanas } \\
\text { Aplicación subcutánea de liberación } \\
\text { mantenida } 1 \mathrm{vez} / \text { semana durante } 8 \text { semanas }\end{array}$ & $\begin{array}{l}\text { Efectos secundarios: } \\
\text { Atrofia cutánea }\end{array}$ \\
\hline Corticoides combinados con minociclina & $\begin{array}{l}\text { Glucocorticoides y minociclina en dosis } \\
2 \times 100 \mathrm{mg} / \mathrm{d} \text { durante } 8 \text { semanas }\end{array}$ & Contraindicados en menores de 8 años \\
\hline Clofamicina & $100 \mathrm{mg} / \mathrm{d}$ durante semanas o meses & $\begin{array}{l}\text { Efectos secundarios:coloración anaranjada } \\
\text { de la piel, problemas gastrointestinales y } \\
\text { corneales }\end{array}$ \\
\hline Talidomida & $50 \mathrm{mg} / \mathrm{d}$ durante $6-8$ semanas & $\begin{array}{l}\text { Efectos secundarios: teratogénesis, } \\
\text { somnolencia }\end{array}$ \\
\hline $\begin{array}{l}\text { Cirugía: } \\
\text { - Queiloplastia labial } \\
\text { - Descompresión quirúrgica del nervio }\end{array}$ & & Más eficaz en combinación con corticoides \\
\hline
\end{tabular}

Table 2. MRS therapeutic options

\section{Therapy \\ Corticoid (prednisolone, triamcinolone): \\ - Topical \\ - Systemic \\ - Intralesional}

Corticoid combined with minocycline

\section{Clofazimine}

Thalidomide

\section{Dosage}

$1 \mathrm{mg} / \mathrm{kg}$ per day for 8 weeks

Subcutaneous release application once a week for 8 weeks

Glucocorticoid and minocycline $2 \times 100 \mathrm{mg}$ per day dosage for 8 weeks

$100 \mathrm{mg}$ per day for weeks or months

$50 \mathrm{mg}$ per day for 6-8 weeks

\section{Effects}

Secondary effects:

Cutaneous atrophy

Contraindicated in children under the age of 8

Secondary effects: orange colored skin, gastrointestinal and corneal problems

Secondary effects: teratogenesis, drowsiness

More effective when combined with corticoids

urgery:

- Lip cheiloplasty

- Surgical decompression of the facial nerve

El tratamiento quirúrgico es una alternativa en caso de deformaciones residuales, pudiendo realizarse una queiloplastia labial, 8 o una descompresión quirúrgica del nervio facia, ${ }^{19}$ en el caso de episodios muy recurrentes que dejen parálisis residuales. Ésta alternativa suele asociarse al tratamiento con corticoides.

En conclusión, los pacientes que sufren un SMR probablemente deban enfrentarse a la recurrencia de sus síntomas durante una gran parte de sus vidas, ya que las alternativas de tratamiento no suelen ser definitivas. Es importante para los profesionales de la cirugía maxilofacial tener estos síntomas en cuenta para poder realizar un correcto diagnóstico de esta infrecuente enfermedad. rent episodes that leave residual paralysis. This alternative tends to be combined with corticoid treatment.

To conclude, patients suffering from MRS probably have to accept that their symptoms will recur for a large part of their lives, as the therapeutic alternatives tend not to be definitive. It is important for professionals in maxillofacial surgery to keep these symptoms in mind so that a correct diagnosis of this rare disease can be carried out. 


\section{Bibliografía}

1. Camacho Alonso F, Bermejo Fenoll A y cols. Queilitis granulomatosa de Meischer: Presentación de cinco casos. Med Oral Patol Oral Cir Bucal 2004;9:425-9.

2. Gerressen M, Ghassemi A, Stockbrink G, y cols. Melkersson-Rosenthal syndrome: case report of a 30-Year Misdiagnosis. J Oral Maxillofac Surg 2005;63:1035-9.

3. Ang KL, Jones NS. Melkersson-Rosenthal Syndrome. The Journal of Laryngology \& Otology 2002;116:386-8.

4. Shapiro M, Peters S, Spinelly HM. Melkersson-Rosenthal Syndrome in the periocular Area: A Review of the literature and Case Report. Ann Plast Surg 2003; 50:644-8.

5. Wolfrang M, Zimmer DDS, Roy S, Rogers III, y cols. Orofacial mani- featations of Melkersson-Rosenthal syndrome. Oral Surg Oral Med Oral Pathol 1992;74:610-9.

6. Michael A, Keefe MD, y cols. Ascher Síndrome. Otolaryngol Head Neck Surg 2001; 124:236-.

7. Gerd Jürgen R, Milo F, Edwin L, y cols. Cheilitis Granulomatosa Miescher: Treatment with Clofamizine and Review of the Literature. Ann Otol Laryngol 2001; 110:964-67.

8. Cederna PS, Fiala TGS, Smith DJ, y cols. Melkersson- Rosenthal Síndrome: Reduction Cheiloplasty Utilizing a Transmodiolar Labial Suspension Suture. Plastic Surgery. Aesthetic Plastic Surg 1998;22:102-5.

9. Dutt SN, Showkat M, Irving RM, y cols. Total Decompression of facial nerve for Melkersson-Rosenthal syndrome. The Journal of Laryngology \& Otology 2000;114: 870-3. 